probably not now growing naturally in the United States, although found on Key. West, according to Nuttall, in Dr. Blodgett's time, have now disappeared from the island; and it is not improbable that other species, which now flourish upon the adjacent islands, have been exterminated from Key West in the general cutting of the woods which is continually going on there.-C. S. SARGENT.

\title{
EDITORIAL.
}

IN REFERRING to the botanical papers at the recent Buffalo meeting of the American Association the American Naturalist takes occasion to remark that "it is noticeable that they include no physiological subjects, and that the tendency is strongly toward the systematic side of botany, which may be taken as indicating the prominent position which this phase of botanical science still maintains with the leaders." In regard to this conclusion we beg to differ, as not necessarily following from the fact stated, and as being contradicted by our own information. The GAZETTE has a wide acquaintance among our most active young botanists, and has had frequent consultations with them as to the most promising field for an energetic young worker to eultivate. A few years, often too few, perhaps, are spent in special and costly preparation of a general kind, and then every spirited student desires to enter some special line of work, in which he proposes to become an authority. The easiest advice to give is that he should follow the bent of his desires, but the average young botanist is compelled rather to follow the bent of his opportunities. Physiological botany is a great department, an exceedingly important and attractive one, and should be cultivated by all who can do so, and we know more than one keen A merican botanist who would willingly exchange all his chances in systematic work for a good opportunity to follow out his physiological bent. But the appliances for good physiological work are costly and entirely beyond the reach of the average American botanist. Of course any amount of physiological work can be conducted in ordinary laboratories, but such work is purely elementary and only serves for class illustration. What our young botanist wants is to become an authority in some department of physiological botany, and how is he to do it with the means at his command? Systematic botany, on the other hand, requires no such unattainable appliances, and what information is needed from unattainable books or specimens can be had by correspondence or an occasional visit to some herbarium where they are to be found. All that is necessary is the selection of some group that needs work (and there are plenty such), the accumulation of all books and specimens possible, and then a settling down to study. As being a thing that can be done, it naturally becomes the thing that is done. We must guard against a too hasty conclusion from these remarks that in our opinion most of our young systematists would be physiologists if they could. There are some among them who would be systematists from choice were the whole field of physiology open to them. We simply make the claim that our young botanists are fully alive to all the interests of their science, physiological as well as systematic, and were equal opportunities offered would be fairly distributed among the different departments. 
BOTANICAL ACTIVITY is manifesting itself by contributions and bulletins from the laboratories and science departments of our various institutions of learning and research. In comparing these one finds that they are of very uneven value as permanent additions to the world's knowledge. They all show ability to deal with new problems, but the worker often leaves the reader to find out for himself just where he stands, and what relation this contribution holds to what other workers have already recorded. We venture to say that the difference in the value of results is mainly referable to the equipment in libraries, specimens and indexes, possessed by the several institutions. Many workers, possibly the majority, are inadequately supplied with these requisites for determining and recording the relation which their results bear to the present record of facts, or for directing their attention to the most profitable part of the field of research. Of these helps, the last is especially important, for unless all available literature and material is fully indexed, by means of a card catalogue or some similar system, it is hopeless to expect the student to thoroughly compass his subject, and to exert his powers to the best. purpose.

\section{OPEN LETTERS.}

\section{Letter from Commissioner Colman.}

\section{To the Members of the Botanical Club of the American Association for the Advancement of Science:}

LAdies AND GEnTLEmEn :- I have noted with extreme gratification the interest you have taken in the work established by me in this Department, relative to the investigation of the fungus diseases of plants; and the resolutions you have passed commending my action and assuring me of your support and aid in securing the necessary means for the continued and successful prosecution of this most important undertaking, are fully appreciated, and I wish to thank you on behalf of the farmers and fruit growers of the country, in whose interest and for whose direct benefit this work is designed.

As you are well aware, only a few of the more important plant diseases have been thoroughly worked out by scientists, and the little that has been donelittle when compared with what there is to do, but a great deal when considered by itself - has been the result of private effort on the part of some of your own well known members. Such obscure diseases as the peach-yellows, the cotton rust and the "foot rot" of the orange tree, demand immediate attention, and, for their proper elucilation, we need to command the services of our most skillful investigators, giving them opportunities to make special studies in the field until the knowledge desired is gained. As you have well suggested a liberal supply of funds is required for this work.

In addition to the assistance in this particular, to which you have so generously pledged yourselves, I beg leave to call your attention to the fact that you, as botanists, knowing our cultivated and native plants and the fungus parasites infesting them, may do much valuable service as observers, in your respective localities, by recording such facts as may come to your notice relating to this subject and by collecting and transmitting to the Department material nseful in the investigations, or that may serve to record the distribution of the injurious species of fungi.

Facilities for this work and a free use of the mails will be accorded those who may have such notes or materials to transmit, and the source of all matter that may be used for publication will be properly credited. 


\section{$2 \mathrm{BHL}$ Biodiversity Heritage Library}

1886. "Editorial." Botanical gazette 11(11), 315-316.

https://doi.org/10.1086/326039.

View This Item Online: https://www.biodiversitylibrary.org/item/87716

DOI: https://doi.org/10.1086/326039

Permalink: https://www.biodiversitylibrary.org/partpdf/221620

\section{Holding Institution}

Missouri Botanical Garden, Peter H. Raven Library

\section{Sponsored by}

Missouri Botanical Garden

\section{Copyright \& Reuse}

Copyright Status: Public domain. The BHL considers that this work is no longer under copyright protection.

This document was created from content at the Biodiversity Heritage Library, the world's largest open access digital library for biodiversity literature and archives. Visit BHL at https://www.biodiversitylibrary.org. 